\title{
裖瘡予防を考慮した座りなおし動作の心理物理学的検討
}

\section{Psychophysical Evaluation of Postural Change for prevention of decubitus}

\author{
○学 迎 寛人（新潟大院） \\ 正 尾田 雅文（新潟大地共研） \\ 正 原 利昭 (新潟大工) \\ 非 田中 正喜（信越化学工業）
}

\begin{abstract}
Hirohito MUKAE, Graduate school of Science \& Technology, Niigata Univ., Ikarashi 2 - 8050, Nishi-ku, Niigata-city, Niigata Masafumi ODA, Center for Cooperative Research, Niigata Univ.

Toshiaki HARA, Faculty of Engineering, Niigata Univ.

Masayoshi TANAKA, Shin-Etsu Chemical Co., Ltd., 6-1, Ohtemachi 2-chome, Chiyoda-ku, Tokyo
\end{abstract}

Key Words: Biomechanics, Medical Support, Welfare Engineering, Human Engineering Design, Contact Pressure, Optimal Design, Stress Alanysis

\section{1. 緒言}

国立社会保障 -人口問題研究所「日本の将来推計予測」に よると, 日本全体における 75 歳以上の後期高齢者の人口割合 は, 2050 年には $20 \%$ 超えると予測されている．また，高齡 被介護者の裖詬有病率を在宅介護と入院・施設間で比較する と，前者は 7.0〜 $14.6 \%$ であるのに対し，後者では 4.2〜9.5\% と在宅で高く，高齢化率の上昇とともに，今後は裖瘡患者も 更に増加することが眯念される. 特に裖瘡の症状が重篤な場 合, 2 年以上の加療を要した症例(1)も報告されていることから, その対策が急務である(2).

裖瘡の発生は, 圧迫荷重の大きさならびにその作用時間や 頻度, さらには栄養状態や湿潤環境など, 様々な要因が関係 しているとされ，さらには，関節近傍をはじめとする骨格形 状が原因と考えられる好発部位が存在する。一般に, 裖瘡予 防を目的としたマットレスは, 力学的観点では体圧分散性能 と姿勢保持性能の双方の機能が重視される．特に前者におい ては，虚血に影響を及ぼす因子であることを鑑みて，介護の 現場では，身体的構造の特徵として骨突出部や関節の位置や 形状についても配虑したマットレス設計(3)(4)が望まれており， 軟部組織に作用する圧迫荷重に起因する圧縮応力のみならず, せん断応力や引張応力についても考慮する必要がある.

そこで本研究では，手術台上で用いられているシリコン樹 脂製マットレスの体圧分散性能に着目し, その特徴を生かし た介護用途の裖瘡予防マットレスの開発を目的とした基礎的 研究の一環として，その体圧分散性能について評価を行った 結果，得られた知見を報告する。

\section{2. 実験方法}

図 1 中(a)に，本研究で用いた実験装置の概要を示す。椅子 上に設置したシリコン樹脂製マットレス上に，被験者が着座 した状態において生ずる接触圧力を, 感圧導電ゴムセンサ (PCR テクニカル製 CSA/MD)を用いて計測した。得られた計 測結果は,データレコーダ(日置電機株式会社製 8860-50)を用 い, サンプリングタイム $100 \mathrm{~ms}$ で一旦記録し, 実験後, パソ コンを用いて解析を行った。ここで, 被験者は 20 歳代の男性 2 名とし, 倫理規定に従い被験者の安全等に配慮して行った。 マットレスは，一辺の長さが $400 \mathrm{~mm}$ の正方形状であり，信越 工業社製シリコン樹脂(KE-1052 A/B) を用いて製作した。な お，厚さは $10 \mathrm{~mm}$ から $100 \mathrm{~mm}$ まで， $10 \mathrm{~mm}$ 間隔で対応可能と した.

実験に際して，着座の初期位置はガイドによって指示する 一方で，着座のまま軽作業を行うこと，ならびに任意に姿勢
変更を行って良い旨を指示した。なお，計測時間は 1 時間と し, 実験開始後, 5 分， 30 分および 60 分後において，「安定 性」「心地よさ」「疲労」等に関する 8 項目の筆記調查を実施 した。.さらに, 被験者足部の床反力を計測可能としており， 体重支持における足部と座面の荷重割合を確認した。

同図中(b)は，感圧導電ゴムセンサの設置位置について示し ている. 同図中に示すように，一辺が $11 \mathrm{~mm}$ の感圧導電ゴム に対し，幅 $10 \mathrm{~mm}$ の電極を両面から挟み込む構造を有する 16 個のセンサを用いた。予備実験において，坐骨近傍において 最も高い接触圧力值を示した $\mathrm{C}$ および $\mathrm{D}$ 点を基準とし，それ ぞれ外側側 $30 \mathrm{~mm}$ 間隔に 3 点，近位側 $40 \mathrm{~mm}$ の位置にそれぞ れ 1 点, 遠位側 $30 \mathrm{~mm}$ の位置に 2 点と $220 \mathrm{~mm}$ の位置に 1 点に ついて, 左右対象となるそれぞれ点を計測個所として選定し た。



Amplifier Data recorder

(a) Experimental setup



(b) Sensor Position

Fig.1 Experiment condition 




Fig. 2 Contact pressure

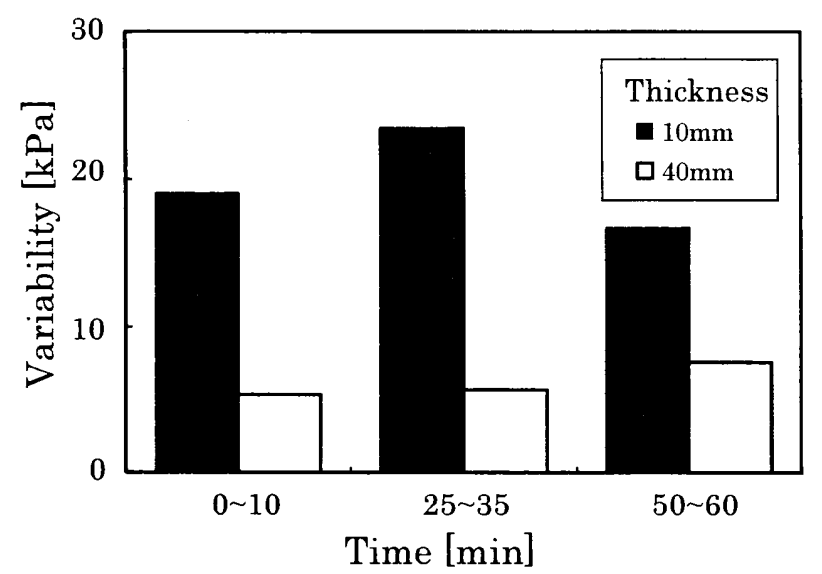

Fig.3 Variability of contact pressure

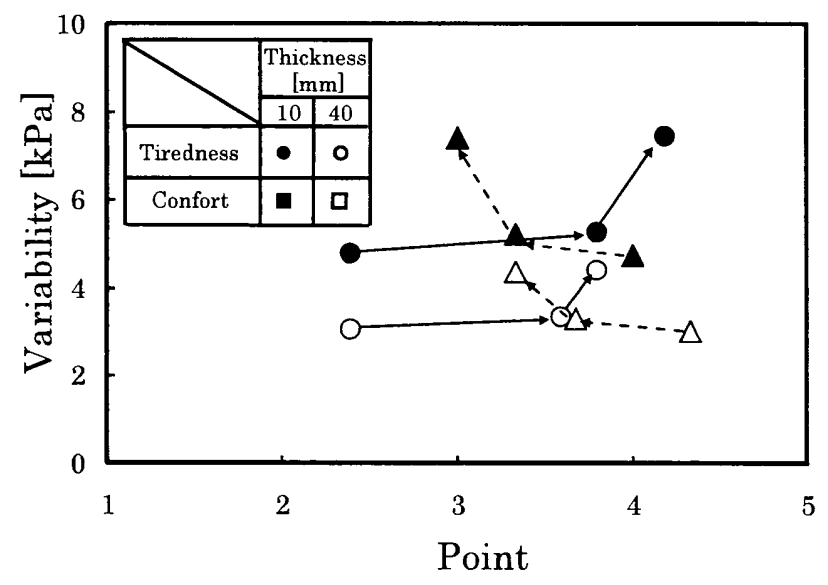

Fig.4 Correlation characteristic

\section{3. 結果および考察}

図 2 は得られた結果の一例であり，体重 $60 \mathrm{~kg}$ ，身長 $168 \mathrm{~cm}$ の健常な成人男性の着座時における接触圧力值を示している. 横軸は，図 1 中における $\mathrm{A}, \mathrm{C}, \mathrm{E}$ ならびに $\mathrm{B}, \mathrm{D}, \mathrm{F}$ の位置にお ける 1 時間の測定データを全て考慮し，併せてそれぞれ左右 対称の位置で平均值を求めた結果を示した。同図より，厚さ $40 \mathrm{~mm}$ のマットレスは，坐骨周辺における接触圧力が最も高 く，遠位，近位の双方で周辺部に向かうに従い，その值は小
さくなる，一方，厚さ $10 \mathrm{~mm}$ の場合は，接触圧力は近位，す なわち着座姿勢における後方に偏って分布している. 特に E, F における值は, 同図中の最大值を示しており,このことか ら, 厚さ $10 \mathrm{~mm}$ に比べ, $40 \mathrm{~mm}$ のマットレスは体圧分散性能 が高いことが示された。ここで, 被験者足部からの荷重伝達 は, 何れのマットレスの場合においても, 被験者の体重の $25 \%$ 程度であり，厚さによる影響は無視できる。

図 3 は, 厚さ $10 \mathrm{~mm}$ および $40 \mathrm{~mm}$ のマットレスについて, それぞれ実験開始後 0 10 分, 25 35 分ならびに 50 60 分にお いて, 図 1 中 $\mathrm{F}$ で示寸位置で得られた接触圧力值の標準偏差 を求めた結果を示したものである. 同図より，何れの計測時 間においても, 厚さ $40 \mathrm{~mm}$ のマットレスに比べ, $10 \mathrm{~mm}$ の標 準偏差值は大きい，接触圧力值の変動は, 姿勢変化に起因す ると考えられ, 標準偏差が小さいことは, すわり心地が比較 的良いことを示しているものと考えられる. 後者において, 実験開始後 30 分までは, 標準偏差が増加傾向にある一方で, その後は減少傾向を示す。これは, 前者においては, 座り直 し動作を繰り返すことで, 血流の改善を行っているのに対し, 後者においては, 如何なる姿勢が快適性を維持できるかを学 習したことにより，その頻度が低下したためと推察される。 一方, $40 \mathrm{~mm}$ については, 計測中, 増加傾向を示す.これは, 時閒経過に対応した疲労等の蓄積で, 座り直し動作回数が増 加したためと考えられる.

図 4 は, 実験開始後 5 分, 30 分および 60 分に実施した筆 記調査結果と, その前後 5 分間の接触圧力值の標準偏差につ いて, 両者の関係を示している。ここで, 筆記調査は,「快適 感」等の 3 項目, ならびに「疲労感」等の 5 項目について, それぞれ 5 段階評価で行っている. そこで,これを点数化し, 前者 3 項目および後者 5 項目について平均值を求め, 接触圧 力の標準偏差との相関を, 実験開始後の経過時間ごとに示し た. なお，3項目については点数が高いほど, 一方, 5 項目に ついては点数が小さいほど，快適であることを示す.

同図より，接触圧力の標準偏差と快適感ならびに疲労感の 間に, 高い相関関係が認められ, 実験開始からの時間経過に 従い, 快適感が損なわれ疲労感が増加し, 標準偏差が増加す ることが判る。すなわち，マットレスと被験者間に作用する 接触圧力分布を継時的に計測・評価することで, マットレス の機能として重要なすわり心地を評価可能と考えられる.

\section{4.結言}

手術台上で用いられているシリコン樹脂製マットレスの体 圧分散性能に着目し, その特徴を生かした福祉用途の裖瘡予 防マットレスの開発を目的とし, その体圧分散性能について, 評価を行った。 さらには, 姿勢保持に対する評価手法を確立 する一環として, 被験者が如何なる心理的状況下で座り直し 動作を行らかについて，検討を行った。

その結果, 本研究の結果加は, 被験者の疲労感, 快適感 の評価に, 標準偏差が重要な指標となることが判った。よっ て, 本研究で提案する手法で, すわり心地の良いマットレス を判定することが可能であることが示唆された.

\section{参考文献}

(1)宮林徹, 日医雑誌, Vol.127, No.11, pp.1866-1867, 2002

(2)Y.Tanimoto, et al., Pressure Measurement for Prevention of Pressure Sore, IEICE technical report, Vol.102, No.575, 2003

(3)T.Yukawa, et al., Quantitative Evaluation Method of Wheelchair Seat Comfort Level, Matsushita Electric Works technical report, Vol.79, pp.73-78, 2002

(4)藤原孝之, 他 2 名, 上半身角度之仙骨·坐骨部の圧変化の動 的解析, 理学療法学, Vol.20, No.1, P.403, 1993 